\title{
Time-Varying Integration of Ukrainian Sunflower Oil Market with the EU Market
}

\author{
Mariusz Hamulczuk ${ }^{1}$, Oksana Makarchuk², Tetyana Kuts² \\ ${ }^{1}$ Department of International Economics and Agribusiness, Warsaw University of Life Sciences - SGGW \\ (Poland) \\ ${ }^{2}$ Department of Statistics and Economic Analysis, Faculty of Economics, National University of Life \\ and Environmental Sciences of Ukraine - NULES of Ukraine
}

\begin{abstract}
Ukraine (UA) is one of the world-leading countries in sunflower oil production and sunflower oil exports. Due to the increasing demand caused by biofuel regulations, the European Union (EU) remains the key importer of Ukrainian sunflower oil. Therefore, the aim of the proposed research is to provide an evaluation of the time-varying integration of the UA sunflower oil market with the EU market. To fulfill this goal, first, the trends in sunflower oil production and exports in Ukraine as well as trade regulations are presented. The market integration was assessed using the ARDL-ECM approach that was applied to weekly sunflower oil prices in the period from 2000 to 2020 . The analytical study was supplemented with the Toda-Yamamoto (T-Y) Granger causality test, the Bai-Perron multiple structural breakpoint test (B-P) as well as impulse response functions (IRF). This study and the obtained results for the whole sample confirm the presence of a long-run relationship between EU and UA prices. The EU prices are the Granger cause for UA prices, as it is shown in the T-Y test. The Bai-Perron test indicates the existence of multiple structural breaks that can be justified by the market condition and policy modifications. Both the long- and the short-run response of UA prices to changes in EU prices vary significantly in different sub-periods.
\end{abstract}

\section{Keywords}

Sunflower oil prices, spatial market integration, ARDL model, Ukraine, European Union.

JEL code: Q13, Q17, Q28

Hamulczuk, M., Makarchuk, O. and Kuts, T. (2021) "Time-Varying Integration of Ukrainian Sunflower Oil Market with the EU Market", A GRIS on-line Papers in Economics and Informatics, Vol. 13, No. 3, pp. 35-47 . ISSN 1804-1930. DOI 10.7160/aol.2021.130304.

\section{Introduction}

\section{Spatial market integration}

The spatial market integration is defined by the extent, to which domestic markets respond to supply and demand shocks in foreign countries. The absence of market integration has important negative implications for economic welfare. Incomplete price transmission arising due to either economic policies or transaction costs may result in inefficient production and irrational consumption decisions. The signals would not be transmitted between the surplus and deficit regions without market integration, prices would be more volatile, specialization would not take place according to the comparative advantage theory and the potential benefits would not be provided by the trade (Fackler and Goodwin, 2001).
The fundamental analysis of spatial market integration is founded on a spatial equilibrium model and the concept of spatial arbitrage (Barrett and $\mathrm{Li}, 2002$ ). If price differences are lower than the trade cost, there is no propensity to trade and shocks are not transmitted between regions. However, if price differences exceed the trade cost, this encourages arbitrageurs to act and transfer goods from the surplus to deficit markets, which is manifested in the co-movement of prices. A perfectly integrated market that passes price information quickly and fully is commonly assumed to be efficient (Bakucs et al., 2019). According to research publications, the transmission of shocks between different regions is frequently related to the Law of One Price (LOP) (Svanidze and Götz, 2019). The LOP states that homogeneous goods in spatially separated markets (locations) will have 
the same price when expressed in the same currency and adjusted by trade costs. The LOP concept is often assumed to be appropriate in the long-run; however, most of the studies indicate deviations from the LOP in the short-run.

However, if trade costs are fluctuating, the propensity to trade also varies and, as a result market integration is not constant over time. Therefore, the long-run equilibrium relationship and short-run price adjustments might be also time-varying. Results of empirical research for agricultural commodities indicate such a possibility (see e.g. Götz et al., 2016). Factors affecting the trade cost and thus agricultural market integration include market infrastructure, foreign and domestic policies, inter-regional imbalances, imperfect competition, product homogeneity or exchange rates (Conforti, 2004; Marwa et al., 2017; Braha et. al., 2019). They alter the market equilibrium by weakening the flows of products between international and domestic markets. Policy instruments are key factors, in turn influencing trade costs. However, it is worth emphasizing that tariffs, tariff-rate quotas, or export and import quotas and bans differently influence market integration and price transmission processes (Rapsomanikis et al., 2006; Listorti and Esposti 2012).

\section{Ukrainian sunflower market}

The global economic growth as well as an increasing role of renewable energy policies have produced new challenges for agriculture over the last decades. The Ukrainian oilseed sector has benefited from these changes. In the last twenty years, the domestic production of sunflower oil has increased over 7-fold, while its export grew 11.5-fold. According to the sunflower oil balance sheet, in the 2019/2020 marketing year (MY) the UA industry produced 7 million tons of sunflower oil, of which $90 \%$ were exported (Table 1).
Ukraine is a major producer and exporter of sunflower oil in the world. In 2019/2020 MY Ukraine had a $30 \%$ share in the world production and a $51 \%$ share in the global sunflower oil trade. In 2000/2001 MY the above-mentioned shares were 13 and $25 \%$, respectively. India, the EU, China and Iraq are the top buyers of Ukrainian sunflower oil. In 2019/2020 MY they collectively purchased over $86 \%$ of Ukraine's annual exports (USDAFAS, 2020).

The key aspects affecting the growth of Ukrainian sunflower oil production and export are domestic and international policies. Ukraine, similarly to most oilseed producing countries worldwide, applies the Differential Export Tax (DET) to promote the export of oil instead of seeds. On the other hand, importing countries as a response to DETs apply import tariffs on vegetable oil, but no tariffs on oilseeds (Bouët et al., 2012). In Ukraine the DETs consist of a single export duty on sunflower seeds, whereas exports of oils and meals are not taxed. The export tax on sunflower seeds (23\%) was introduced in 1999; however, it was reduced to $17 \%$ in 2001 and to $16 \%$ in 2005. After accession to the World Trade Organization (WTO) in 2008 the export tax rates were gradually decreased to $10 \%$ in 2013 (Shmygol et al., 2013; Tulush and Hryshchenko, 2018). As a result of such a policy, almost all grown sunflower seeds are domestically consumed or processed for sunflower oil.

The biofuel policy has also contributed to the increase of Ukrainian production and export of vegetable oils. Proposed requirements and biofuel regulations introduced by developed countries have significantly influenced agricultural markets worldwide, even in the countries which did not support such initiatives (Zilberman et al. 2013; Hamulczuk et al., 2019). The EU biofuel policy was crucial for the development of the oilseed markets

\begin{tabular}{|l|c|c|c|c|c|}
\hline Marketing year & $2000 / 2001$ & $2005 / 2006$ & $2010 / 2011$ & $2015 / 2016$ & $2019 / 2020$ \\
\hline Beginning Stocks & 12 & 293 & 144 & 344 & 40 \\
\hline Production & 970 & 1925 & 3335 & 5010 & 7055 \\
\hline Imports & 0 & 0 & 1 & 1 & 0 \\
\hline Total Supply & 982 & 2218 & 3480 & 5355 & 7095 \\
\hline Exports & 550 & 1514 & 2652 & 4500 & 6350 \\
\hline Domestic Consumption & 417 & 417 & 530 & 550 & 545 \\
\hline Total Demand & 967 & 1931 & 3182 & 5050 & 6895 \\
\hline Ending Stocks & 15 & 287 & 298 & 305 & 200 \\
\hline Self-sufficiency ratio & 2.33 & 4.62 & 6.29 & 9.11 & 12.94 \\
\hline
\end{tabular}

Source: the authors' calculations based on USDA-FAS (2020)

Table 1: Sunflower oil balance sheet for Ukraine, thousand MT. 
in Ukraine (Kretschmer et al. 2012). As a result of the increased demand for sunflower oil, the EU has become the main export destination for Ukrainian sunflower oil. The volume of sunflower oil exports from Ukraine to the EU has increased around 13-fold in the last 20 years (USDA-FAS, 2020). This tendency confirms the increase in the integration of these markets, measured by the flow of goods.

\section{The purpose of the study}

Nowadays, globalization and international integration processes in agriculture and food commodity markets may lead to the trade creation and trade diversion effects. The fluctuation of trade barriers resulting from changes in customs rates, non-tariff restrictions and transportation costs, as well as multilateral or bilateral agreements will potentially result in the time-varying linkage of international agricultural and food markets. In this context, questions related to the nature of price linkages between agri-food markets in various countries or regions and the strength of these links remain problems of current importance. The literature on the spatial integration of Ukrainian agricultural commodity markets is limited in scope mostly to grain markets (e.g., Goychuk and Meyers 2014; Potori and Józsa, 2014; Götz et al., 2016) or the rapeseed market (Hamulczuk et al., 2019). Some of these sources refer to the potential time-varying linkage between the markets. Despite the importance of sunflower seed and sunflower oil markets in Ukraine, few papers published by Ukrainian researchers are related to the economic aspects of these markets. Instead, most of them focus on general policy, market efficiency and international marketing issues (e.g., Shpychak et al., 2015; Barsuk, 2017; Tulush and Hryshchenko, 2018). To our best knowledge, the only paper related to the investigation of price linkages between Ukrainian and international sunflower markets is by Kuts and Makarchuk (2020). However, the research presented there is based on monthly data and does not refer to the possible changes in the strength of price transmission over time.

Taking into account all the issues indicated above, the aim of this paper is to evaluate the nature of the time-varying integration of the UA sunflower oil market with the EU market. In this study the price linkage between sunflower seeds was not analyzed, because it is sunflower oil, not the seeds, that is the subject of bulk international trade. In our opinion, this is the first study being an attempt to assess the spatial integration of UA with foreign sunflower oil markets based on the price transmission approach. To fulfill this goal the Granger causality test, the ARDL-ECM model and multiple structural breakpoint tests of Bai-Perron were applied based on weekly price data in 2000-2020. To facilitate the interpretation of price adjustments the accumulated Impulse Response Functions (IRF) were estimated. To provide specific insight, the rest of the paper is structured as follows: section 2 presents data and methods of empirical investigation, section 3 reports on the results and provides their discussion and the conclusions are presented at the end of this paper.

\section{Materials and methods}

Spatial market integration can be measured using different approaches and data (see e.g., Barrett and Li, 2002; Listorti and Esposti, 2012). Nevertheless, two concepts dominate in the literature on the subject. In one approach the integration is referred to as the process of interlinkages between market participants, which are reflected by the trade flows. The other concept refers to the co-movement of prices in various locations resulting in both the trade and information flows. The price approach was used in this study to assess the nature of UA and EU sunflower oil market integration. The coverage period of the weekly sunflower oil price series extends from January 2000 until July 2020 (Figure 1). Ukrainian sunflower oil prices are ex-works, whereas the UE data are FOB prices in Rotterdam, being the representative market for the EU.

The first step in the preliminary analysis includes testing the order of integration for price series with the use of the Augmented Dickey-Fuller (ADF) test. In order to determine the endogeneity of the variables, the Toda-Yamamoto (T-Y) causality test based on the ARDL approach is performed. This test is based on the pair of equations similar to Equation 1, but without the contemporaneous lag (see for details Toda and Yamamoto, 1995).

After the preliminary analysis had been performed, it was decided to use the ARDL-ECM approach (Pesaran et al., 2001). The applied method has some advantages over the conventional co-integration analysis, because it can be used regardless of the fact whether the underlying series are $\mathrm{I}(0)$, I(1), or even fractionally integrated. The only restriction is that the analyzed series cannot be I(2) integrated. This model can also include contemporaneous price reactions. The general version of the ARDL ( $p, q)$ model for two price 


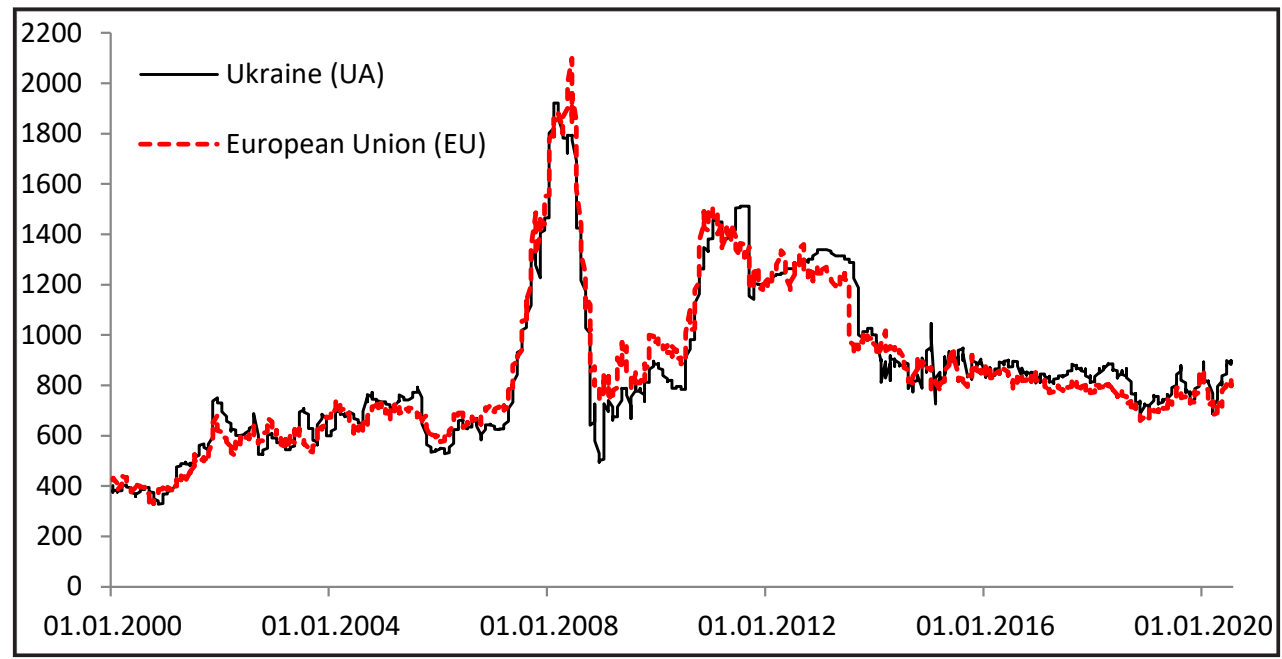

Source: the authors' study based on APK-Inform

Figure 1: Weekly sunflower oil price series used in the study (USD/metric ton).

series $\left(\mathrm{Y}_{\mathrm{t}}\right.$ and $\left.\mathrm{X}_{\mathrm{t}}\right)$ may be presented as follows:

$$
\mathrm{Y}_{t}=\mu_{0}+\mu_{1} t+\sum_{i=1}^{p} \alpha_{i} \mathrm{Y}_{t-1}+\sum_{i=0}^{q} \beta_{i} \mathrm{X}_{t-i}+\varepsilon_{t}
$$

where: $Y_{t}, X_{t}$ are dependent and independent variables, respectively (in our case $Y_{t}$ is Ukrainian sunflower oil price and $X_{t}$ is EU sunflower oil price, the booth in logs), $\mu_{0}$ and $\mu_{t} t$ reflect the deterministic part of the model (constant and linear trends), $\alpha_{i}$ and $\beta_{i}$ are other parameters, $\varepsilon_{\mathrm{t}}$ denotes white noise errors. The number of lags $(p, q)$ can be adopted based on information criteria assuring no autocorrelation in residuals (LM test). The model can be estimated OLS or other robust methods (e.g., HAC). The above model may be transformed into an unrestricted (conditional) ARDL-ECM form that may be used for co-integration testing:

$$
\begin{aligned}
\Delta \mathrm{Y}_{t} & =\mu_{0}+\mu_{1} t+\sum_{i=1}^{p-1} \alpha_{i} \Delta \mathrm{Y}_{t-i}+\sum_{i=0}^{q-1} \beta_{i} \Delta \mathrm{X}_{t-i}+ \\
& +\pi_{1} \mathrm{Y}_{t-1}+\pi_{2} \Delta \mathrm{X}_{t-1}+\varepsilon_{t}
\end{aligned}
$$

where: $\alpha_{i}$ and $\beta_{i}$ represent short-run dynamics, $\pi_{1}$ and $\pi_{2}$ allow us to estimate the long-run relationship.

The existence of the long-run relationship between the variables was tested based on F-test statistics. The null hypothesis of no co-integration (H0: $\left.\pi_{1}=\pi_{2}=0\right)$ is tested against an alternative hypothesis assuming the presence of co-integration between the variables $\left(\mathrm{H} 1: \pi_{1} \neq \pi_{2} \neq 0\right)$. Calculated F-test statistic values are compared with two sets of critical values, after Pesaran et al. (2001). If the F-statistic is below the lower bound critical value, then the null hypothesis of no co-integration cannot be rejected. When the F-test statistics exceeds the upper critical value, then the null hypothesis of no co-integration can be rejected. If the computed F-statistic falls between the lower and upper bounds, then the results are inconclusive.

Taking into account possible time-varying price transmission, the stability of parameters was tested by the CUSUM standard and CUSUMSQ tests (Brown et al., 1975). Moreover, to test the parameter stability and structural change in the ARDLECM models different versions of the Bai-Perron multiple breaks test were applied (Bai and Perron, 1998). These tests were conducted on the $\mathrm{L}+1$ vs. $\mathrm{L}$ sequentially determined breaks, L+1 vs. L globally determined breaks and 1 to $\mathrm{M}$ globally determined breaks. After assuming the structural breaks new ARDL-ECM models for each subsample were estimated. The whole analysis was summarized by computing dynamic multipliers (IRF), which show the amount of information each exogenous variable contributes to the endogenous one. The empirical analysis was performed and presented in two dimensions: a) for the whole sample (assuming no time-varying price transmission, which can be the starting point for the next step), and b) assuming and testing time-varying price transmission.

\section{Results and discussion}

\section{The whole sample analysis}

The empirical analysis was started with the unit root test (ADF) for the logarithmic price series as well as their first differences (d). In the entire 
study sample, it can be concluded that no series is integrated of order two I(2). The ADF test indicates that $\operatorname{logs}$ of the UA series are stationary (the null hypothesis assuming non-stationarity is rejected at $5 \%$ significance levels ( $\mathrm{t}-\mathrm{stat}=2.93, \mathrm{p}=0.043$ ), whereas logs of the EU price series are integrated of order 1 (Table 2). The results of the ADF test for price series justified the use of the ARDL-ECM framework, which is robust for the non-stationarity assumption in testing long-run relationships.

\begin{tabular}{|l|c|c|}
\hline \multicolumn{3}{|c|}{ ADF test } \\
\hline Variable & No. of lags & t-stat \\
\hline UA & 14 & $-2.927^{* *}$ \\
\hline d_UA & 13 & $-7.258^{* * *}$ \\
\hline EU & 6 & $-2.581^{*}$ \\
\hline d_EU & 5 & $-10.897^{* * *}$ \\
\hline \multicolumn{3}{|c|}{ Toda-Yamamoto causality test } \\
\hline Independent variable & No. of lags & F-stat \\
\hline EU & 9 (AIC) & $10.662^{* * *}$ \\
\hline UA & 9 (AIC) & $1.769^{*}$ \\
\hline
\end{tabular}

Source: the authors' study

Table 2: Results of unit root and Granger causality tests (based on log data).

It was expected that UA prices are endogenous to prices in the EU. To verify this hypothesis the Toda-Yamamoto test based on the ARDL model was applied (Equation 1), but without taking into consideration the contemporaneous lag and assuming $p=q$ (see details in Toda and Yamamoto, 1995). Due to the heteroscedasticity, the testing model was estimated with the HAC standard errors. Optimal lags were established using the Akaike information criterion (AIC) based on the VAR model ( $p=q=9$ ) and increased by one due to the integration of the EU series. The T-Y results clearly indicate that EU prices are the Granger cause for UA prices. The null hypothesis stating that UA prices do not Granger-cause the EU prices was not rejected at the 5\% significance level. This justifies adoption in formulas 1 and 2 UA prices as the $Y_{t}$ variable and EU prices as the $X_{t}$ variable.

Subsequently, different versions of the $\operatorname{ARDL}(\mathrm{p}, \mathrm{q})$ model (Eq. 1) were estimated (taking into account the deterministic components, the number of lags and the estimation method). According to the Bayesian information criterion (BIC) the suggested model is the $\operatorname{ARDL}(2,3)$, according to the Schwarz information criterion (SIC) it is the ARDL(6,3), whereas using the AIC criterion indicates the $\operatorname{ARDL}(9,9)$. The aforementioned models are suggested regardless of the set of deterministic components. Due to the fact that all models estimated via an OLS suffer heteroscedasticity problems it was decided to use the Newey-West HAC estimator.

The residual autocorrelation was tested by the Breusch-Godfrey LM test. The ARDL $(2,3)$ model (which is a very parsimonious model) suffers from the serial autocorrelation for the 4-6 week span. No such problem was found for the other models, thus it was decided to use the ARDL $(6,3)$ model suggested by the HQ criterion, which is a compromise between the AIC and SC criteria. Subsequently, the ARDL$\operatorname{ECM}(6,3)$ model was estimated with different sets of deterministic components (Table 3 ).

The applied bound co-integration test confirmed the existence of a statistically significant long-run equilibrium relationship between the UA and EU prices. In all the models, the calculated $\mathrm{F}$ statistics are over the upper bound critical value at the $1 \%$ significance levels. Relying on the ARDL-ECM models, the long-run equilibrium relationships were estimated (Table 3). In the long-run a $1 \%$ increase in EU sunflower oil prices causes an increase in sunflower oil prices in Ukraine ranging from $0.91 \%$ (the model with the unrestricted constant and the restricted trend) to $1.00 \%$ (the model without a constant). The results also indicate that after the shock the Ukrainian sunflower oil prices are adjusting to the long-run equilibrium at a rate of 5.5-6.2\% per week. Kuts and Makarchuk (2020) using monthly price series and Engle-Granger co-integration test also confirmed the long-run equilibrium relationship between $\mathrm{UA}$ and $\mathrm{EU}$ sunflower prices. Employing that methodology they also obtained the long-run equilibrium relationship coefficient (0.98) which is similar to ours and confirmed the Granger causality from EU to UA prices.

We ignored the multicollinearity of variables in estimated ARDL-ECM models as most researchers do. In theory, multicollinearity only increases the parameter uncertainty while coefficients are still unbiased. In our case (these concerns models estimated for the whole sample as well as models with structural breaks), strong multicollinearity measured by Variable Inflation Factors (VIF) takes place only for variables on levels while there is no such problem for differenced variables (see formulas 1 and 2). This is understandable because cointegrated variables are also correlated which results in a high VIF. However, the possible further transformation 


\begin{tabular}{|c|c|c|c|}
\hline Variable & No const. & Unrestricted const. & Unrest. const. and rest. trend \\
\hline d_UA(-1) & $0.243 * * *$ & $0.243 * * *$ & $0.245^{* * *}$ \\
\hline d_UA(-2) & -0.010 & -0.009 & -0.006 \\
\hline d_UA(-3) & -0.035 & -0.034 & -0.031 \\
\hline d_UA(-4) & $0.049^{*}$ & $0.050^{*}$ & $0.053^{*}$ \\
\hline d_UA(-5) & $0.105 * * *$ & $0.106 * * *$ & $0.111 * * *$ \\
\hline d_EU & $0.190 * * *$ & $0.187 * * *$ & $0.188^{* * *}$ \\
\hline d_EU(-1) & $0.182 * * *$ & $0.181 * * *$ & $0.179 * * *$ \\
\hline d_EU(-2) & $0.142 * * *$ & $0.142 * * *$ & $0.140 * * *$ \\
\hline $\mathrm{EU}(-1)$ & $0.055 * * *$ & $0.053 * * *$ & $0.056^{* * *}$ \\
\hline $\mathrm{UA}(-1)$ & $-0.055 * * *$ & $-0.056 * * *$ & $-0.062 * * *$ \\
\hline $\mathrm{C}$ & - & 0.019 & $0.033 * *$ \\
\hline Trend & - & - & $6.06 \mathrm{E}-06^{* *}$ \\
\hline Description & \multicolumn{3}{|c|}{ Bound co-integration test } \\
\hline F Stat. & 20.394 & 21.158 & 15.649 \\
\hline CV $10 \%$ & $\mathrm{I}(0)=2.44 \mathrm{I}(1)=3.28$ & $\mathrm{I}(0)=4.04 \mathrm{I}(1)=4.78$ & $\mathrm{I}(0)=4.05 \mathrm{I}(1)=4.49$ \\
\hline CV 5\% & $\mathrm{I}(0)=3.15 \mathrm{I}(1)=4.11$ & $\mathrm{I}(0)=4.94 \mathrm{I}(1)=5.73$ & $\mathrm{I}(0)=4.68 \mathrm{I}(1)=5.15$ \\
\hline CV $1 \%$ & $\mathrm{I}(0)=4.81 \mathrm{I}(1)=6.02$ & $\mathrm{I}(0)=6.84 \mathrm{I}(1)=7.84$ & $\mathrm{I}(0)=6.10 \mathrm{I}(1)=6.73$ \\
\hline Coint. Eq. & $\mathrm{UA}=1.00 * \mathrm{EU}$ & $\mathrm{UA}=0.95 * \mathrm{EU}$ & $\mathrm{UA}=0.91 * \mathrm{EU}+0.0001 * \mathrm{TREND}$ \\
\hline Lag & \multicolumn{3}{|c|}{ Breusch-Godfrey serial correlation LM test (F stat) } \\
\hline 4 & 1.839 & 1.915 & $2.099^{*}$ \\
\hline 6 & 1.540 & 1.636 & $1.830^{*}$ \\
\hline 8 & $2.038^{* *}$ & $2.134 * *$ & $2.263 * *$ \\
\hline
\end{tabular}

Source: the authors' study

Table 3: ARDL-ECM(6,3) estimated model and bound co-integration test.

of the model given by formula 2 (estimated and presented in tables 3,5 , and 6) by replacing $Y_{t-1}$ and $X_{t-1}$ with the error correction term (ECT) eliminates this problem with the rest coefficients being unchanged. This shows that the coefficient estimates of the ARDL-ECM models seem to be robust to the problems of heteroscedasticity.

In ARDL models, the evaluation of autocorrelation is crucial for the quality of the model. Errors of estimated models are not serially correlated for lags up to 4 , but there are problems with the correlation for lags greater than 6 weeks (Breusch-Godfrey LM test). The increase in the number of lags in models only reduces the autocorrelation up to the order of the applied lags. Autocorrelations for higher orders are still significant. This also suggests that the coefficients of the ARDL-ECM model may change over time. This supposition seems to be confirmed by the CUSUM test for squared residuals suggesting structural breaks in coefficients or in volatility.

\section{Time-varying price transmission}

Taking into account possible changes in the strength of price adjustments due to factors discussed in the introduction, it was decided to apply several versions of the Bai-Perron test for multiple structural breaks at an unknown point. Testing has an advantage over the subjective determination of the moments of structural changes, because it takes into account all known and unknown factors influencing the price transmission. These tests were applied to the ARDL $(6,3)$ models with different sets of deterministic components. It was assumed that all the independent variables may cause structural changes (thus their coefficients may change over time) and residuals in different sub-periods may have different distributions. These assumptions allow us to determine different price transmission regimes arising from changes in price levels, the speed of response of market agents as well as price risk. Table 4 shows the results for the application of different variants of BaiPerron multiple breakpoint tests at the 5\% significance level. These results significantly differ depending on the type of the test used and assumed deterministic components. It needs to be emphasized here that in all the cases the structural change was detected for 2014.

In the further part of the study two models with constants were estimated. One model assumed three structural breaks, while the other contained 
5 structural changes (see bolded break dates in Table 4). Coefficients of estimated unrestricted (conditional) ARDL-ECM models (Equation 2) as well as results of bound co-integration tests are presented in Tables 5 and 6 . The tables also include results of the ADF unit root and T-Y Granger causality tests in particular subsamples. For these tests, the optimal number of lags was newly determined based on the AIC. Since none of the time series in individual sub-periods is integrated of order two, it is possible to use the ARDL models.

In the first presented model (Table 5) we have four sub-periods that differ significantly from each other. Until 2006, UA was exporting little sunflower oil to the EU. Nevertheless, due to the international trade and information flows the prices of sunflower oil in Ukraine and in the EU were co-integrated.
In 2006-2010, sunflower oil prices were highly volatile due to increasingly active biofuel policies and the economic crisis. As a result, sunflower oil prices in UA and the EU in 2006-2010 are characterized by a lack of co-integration at the significance level of 5\%. This is the only period, in which we deal with bidirectional Granger causality. In the other sub-periods, the prices in Ukraine adjusted to those in the EU and not the other way around. In 2010-2014, there was a further increase in price linkages. Since 2014, along with the saturation of the biofuel market and the fall in world crude oil prices, the long-run price linkage has weakened.

The price adjustments in the model with 5 structural breaks are slightly more complex (Table 6). Here, we are dealing with two bidirectional Granger sub-periods: 2000-2003

\begin{tabular}{|c|c|c|c|}
\hline B-P test variant & No constant & Constant & Constant + trend \\
\hline $\begin{array}{l}\mathrm{L}+1 \text { vs. } \mathrm{L} \text { sequentially } \\
\text { determined breaks }\end{array}$ & $\begin{array}{l}3 / 31 / 2006,30 / 7 / 2010 \\
14 / 11 / 2014^{*}\end{array}$ & $\begin{array}{l}\text { 29/9/2006, } 05 / 11 / 2010, \\
14 / 11 / 2014\end{array}$ & $07 / 3 / 2014$ \\
\hline $\begin{array}{l}\mathrm{L}+1 \text { vs. } \mathrm{L} \text { globally determined } \\
\text { breaks }\end{array}$ & $\begin{array}{l}31 / 3 / 2006,30 / 7 / 2010 \\
14 / 11 / 2014\end{array}$ & $\begin{array}{l}\text { 11/4/2003, 29/9/2006, } \\
05 / 11 / 2010,14 / 11 / 2014\end{array}$ & $\begin{array}{l}18 / 4 / 2003,29 / 06 / 2006, \\
17 / 12 / 2010,14 / 1 / 2014\end{array}$ \\
\hline $\begin{array}{l}1 \text { to } \mathrm{M} \text { globally determined } \\
\text { breaks: sequential F-statistic }\end{array}$ & $\begin{array}{l}25 / 4 / 2003,29 / 9 / 2006, \\
30 / 7 / 2010,07 / 3 / 2014, \\
21 / 4 / 2017\end{array}$ & $\begin{array}{l}25 / 4 / 2003,29 / 9 / 2006, \\
09 / 7 / 2010,07 / 2 / 2014, \\
03 / 3 / 2017\end{array}$ & $\begin{array}{l}18 / 4 / 2003,12 / 5 / 2006 \\
17 / 7 / 2009,07 / 2 / 2014, \\
03 / 3 / 2017\end{array}$ \\
\hline $\begin{array}{l}1 \text { to } \mathrm{M} \text { globally determined } \\
\text { breaks: highest significant } \\
\text { F-statistic }\end{array}$ & $\begin{array}{l}25 / 4 / 2003,29 / 9 / 2006, \\
30 / 7 / 2010,07 / 3 / 2014, \\
21 / 4 / 2017\end{array}$ & $\begin{array}{l}25 / 4 / 2003,29 / 9 / 2006, \\
09 / 7 / 2010,07 / 2 / 2014, \\
03 / 3 / 2017\end{array}$ & $\begin{array}{l}18 / 4 / 2003,12 / 5 / 2006, \\
17 / 7 / 2009,07 / 2 / 2014, \\
03 / 3 / 2017\end{array}$ \\
\hline $\begin{array}{l}1 \text { to } M \text { globally determined } \\
\text { breaks: UDmax }\end{array}$ & $07 / 3 / 2014$ & $07 / 3 / 2014$ & $07 / 3 / 2014$ \\
\hline $\begin{array}{l}1 \text { to } M \text { globally determined } \\
\text { breaks: WDmax }\end{array}$ & $07 / 3 / 2014$ & $\begin{array}{l}25 / 4 / 2003,29 / 9 / 2006, \\
09 / 7 / 2010,07 / 2 / 2014, \\
03 / 3 / 2017\end{array}$ & $\begin{array}{l}18 / 4 / 2003,12 / 5 / 2006, \\
17 / 7 / 2009,07 / 2 / 2014, \\
03 / 3 / 2017\end{array}$ \\
\hline
\end{tabular}

Note: *Dates: day/month/year

Source: the authors' study

Table 4: Break dates in the ARDL(6,3) model according to Bai-Perron multiple breakpoint tests (HAC estimation).

\begin{tabular}{|l|c|c|c|c|}
\hline Time span & $\mathbf{2 / 2 0 0 0 - 9 / 2 0 0 6}$ & $\mathbf{9 / 2 0 0 6 - 1 0 / 2 0 1 0}$ & $\mathbf{1 1 / 2 0 1 0 - 1 1 / 2 0 1 4}$ & $\mathbf{1 1 / 2 0 1 4 - 7 / 2 0 2 0}$ \\
\hline Variable & \multicolumn{3}{|c|}{ Model coefficients } \\
\hline d_UA(-1) & $0.470 * * *$ & $0.406 * * *$ & 0.020 & 0.151 \\
d_UA(-2) & -0.049 & -0.075 & 0.029 & 0.043 \\
d_UA(-3) & $0.210 * * *$ & $-0.138^{*}$ & 0.031 & -0.083 \\
d_UA(-4) & $-0.113^{* *}$ & $0.134 * *$ & -0.010 & 0.040 \\
d_UA(-5) & 0.041 & $0.157 * *$ & -0.077 & $0.166 * * *$ \\
d_EU & $0.068 *$ & $0.294 * * *$ & $0.270 * *$ & 0.053 \\
d_EU(-1) & $0.070 * *$ & $0.265 * * *$ & -0.005 & 0.092 \\
d_EU(-2) & $0.128 * * *$ & $0.104 *$ & -0.017 & 0.054 \\
EU(-1) & $0.049 * * *$ & $0.129 *$ & $0.111 * * *$ & $0.234 * * *$ \\
UA(-1) & $-0.051 * * *$ & $-0.120^{* *}$ & $-0.090 * * *$ & $-0.280^{* * *}$ \\
C & 0.014 & $-0.074 *$ & $-0.148 * *$ & $0.324 *$ \\
\hline
\end{tabular}

Source: the authors' study

Table 5: The ARDL-ECM(6,3) model with 3 breaks (HAC estimation) (to be continued). 


\begin{tabular}{|c|c|c|c|c|}
\hline Time span & 2/2000-9/2006 & 9/2006-10/2010 & $11 / 2010-11 / 2014$ & $11 / 2014-7 / 2020$ \\
\hline Description & \multicolumn{4}{|c|}{ Bound co-integration test } \\
\hline F Stat. & 14.603 & 4.010 & 7.292 & 11.288 \\
\hline CV $10 \%$ & \multicolumn{4}{|c|}{ Restricted const. $\mathrm{I}(0)=3.02 \mathrm{I}(1)=3.51 /$ Unrestricted const. $\mathrm{I}(0)=4.04 \mathrm{I}(1)=4.78$} \\
\hline CV $5 \%$ & \multicolumn{4}{|c|}{ Restricted const. $\mathrm{I}(0)=3.62 \mathrm{I}(1)=4.16 /$ Unrestricted const. $\mathrm{I}(0)=4.94 \mathrm{I}(1)=5.73$} \\
\hline $\mathrm{CV} 1 \%$ & \multicolumn{4}{|c|}{ Restricted const. $\mathrm{I}(0)=4.94 \mathrm{I}(1)=5.58 /$ Unrestricted const. $\mathrm{I}(0)=6.84 \mathrm{I}(1)=7.84$} \\
\hline Coint. Eq. & $\mathrm{UA}=0.96 \mathrm{EU}$ & $\mathrm{UA}=1.07 \mathrm{EU}$ & $\mathrm{UA}=1.24 \mathrm{EU}$ & $\mathrm{UA}=0.83 \mathrm{EU}$ \\
\hline Lag & \multicolumn{4}{|c|}{ Breusch-Godfrey serial correlation LM test (F stat) } \\
\hline 4 & \multicolumn{4}{|c|}{0.871} \\
\hline 8 & \multicolumn{4}{|c|}{0.744} \\
\hline Variable & \multicolumn{4}{|c|}{ ADF test statistics } \\
\hline UA & -2.051 & -1.689 & 0.204 & $-3.091 * *$ \\
\hline d_UA & $-7.386 * * *$ & $-4.612 * * *$ & $-13.791 * * *$ & $-7.435 * * *$ \\
\hline EU & -1.448 & -1.881 & -0.440 & -2.391 \\
\hline d_EU & $-17.946^{* * *}$ & $-3.598 * * *$ & $-7.376^{* * *}$ & $-16.924 * * *$ \\
\hline Independent var. & \multicolumn{4}{|c|}{ Toda-Yamamoto causality test statistics } \\
\hline UE & $6.662 * * *$ & $7.751 * * *$ & $3.674 * *$ & $15.294 * * *$ \\
\hline UA & 1.772 & $3.446 * *$ & 1.393 & 1.873 \\
\hline
\end{tabular}

Source: the authors' study

Table 5: The ARDL-ECM(6,3) model with 3 breaks (HAC estimation) (continuation).

and 2006-2010. Additionally, in 2014-2017 the UA sunflower oil prices are a Granger cause for EU and not the other way around. In this period, the coefficient for the long-run relationship was only 0.33 . This model, similarly to the model in Table 5, also confirmed the lack of price co-integration in 2006-2010 at the 5\% significance level.

Interpretation of price adjustments was facilitated by the use of cumulated Impulse Response Functions (IRF) (see Figure 2). These charts show the percentage response of Ukrainian prices to a $1 \%$ change in EU prices for the models estimated in Tables 5 and 6 . In the following paragraphs, when discussing the possible reasons for the change in the speed and strength of price transmission, and hence the sunflower oil market integration, we will mainly refer to the model with 5 structural breaks.

From the Figure 2, it can be seen that in the years 2000-2010 the strength of Ukrainian price adjustments to EU prices was gradually increasing. It concerned both the short-run price adjustments as well as the long-run price transmission. This may be explained by the gradual surge in sunflower oil exports to the EU caused mostly by the increased demand for vegetable oils in the EU related to the biofuel policy. In 2000-2010 total sunflower oil import from Ukraine to the EU increased 40 -folds - from \$ 16 million to \$ 644 million (Comtrade 2020). At the same time, EU biodiesel production increased 13.6 times. Thus, it can be noted that the reduction of the Differential Export Tax on sunflower seeds by Ukraine from $23 \%$ to $13 \%$ (see Shmygol et al., 2013; Tulush and Hryshchenko, 2018) at that time did not have any significant impact on reducing the competitiveness of Ukrainian sunflower oil exports.

In 2006-2010, the short-run price adjustments between UA and EU sunflower oil prices were the strongest. It was the period of the so-called biofuel boom during which many European Union countries were not able to meet the requirements set by the European Commission in the field of biofuel blending rates. As a result, the import demand for vegetable oils in the EU significantly increased (Comtrade 2020). In the light of the EU-28 Biofuels Annual Report (USDA-FAS 2020), sunflower oil constitutes only $2-5 \%$ of feedstock used for biodiesel and renewable diesel production in the EU. Although sunflower oil is hardly used for the production of biofuels, it is an excellent substitute for rapeseed oil or palm oil. Hence, the situation on the sunflower oil market and the horizontal transmission of prices between UA and EU are also strongly dependent on the biofuel policy in the European Union.

The combination of many events caused the price transmission to decline in the period from July 2010 to February 2017. Of which the weakest price links were observed from February 2014 


\begin{tabular}{|c|c|c|c|c|c|c|}
\hline Time span & $2 / 2000-4 / 2003$ & 4/2003-9/2006 & 9/2006-7/2010 & $7 / 2010-1 / 2014$ & 2/2014-2/2017 & $3 / 2017-7 / 2020$ \\
\hline Variable & \multicolumn{6}{|c|}{ Model coefficients } \\
\hline d_UA(-1) & $0.582 * * *$ & $0.361 * * *$ & $0.411 * * *$ & $0.551 * * *$ & 0.094 & 0.059 \\
\hline d_UA(-2) & -0.129 & 0.085 & -0.077 & -0.162 & 0.059 & 0.003 \\
\hline d_UA(-3) & 0.089 & $0.353 * * *$ & $-0.140 *$ & -0.100 & 0.013 & -0.040 \\
\hline d_UA(-4) & -0.055 & $-0.188 * * *$ & $0.142 * *$ & $0.163 * *$ & 0.046 & 0.064 \\
\hline d_UA(-5) & 0.049 & -0.039 & $0.159 * *$ & -0.072 & 0.151 & 0.046 \\
\hline d_EU & 0.015 & $0.174 * *$ & $0.291 * * *$ & $0.218 * *$ & 0.027 & 0.192 \\
\hline d_EU(-1) & $0.076^{* *}$ & $0.123^{*}$ & $0.285^{* * *}$ & $-0.074 *$ & -0.077 & $0.252 * *$ \\
\hline d_EU(-2) & $0.179 * * *$ & 0.020 & 0.097 & 0.033 & 0.024 & 0.093 \\
\hline $\mathrm{EU}(-1)$ & $0.044 * * *$ & $0.045^{* * *}$ & $0.131 * *$ & $0.073 * * *$ & $0.127 * *$ & $0.203 * * *$ \\
\hline $\mathrm{UA}(-1)$ & $-0.046^{* * *}$ & $-0.048 * * *$ & $-0.122 * * *$ & $-0.081 * * *$ & $-0.380 * * *$ & $-0.189 * * *$ \\
\hline $\mathrm{C}$ & 0.012 & 0.016 & -0.078 & 0.063 & $1.716 * * *$ & -0.081 \\
\hline Description & \multicolumn{6}{|c|}{ Bound co-integration test } \\
\hline F Stat. & 6.565 & 6.004 & 3.327 & 6.677 & 6.154 & 7.845 \\
\hline CV $10 \%$ & \multicolumn{6}{|c|}{ Restricted const. $\mathrm{I}(0)=3.02 \mathrm{I}(1)=3.51 /$ Unrestricted const. $\mathrm{I}(0)=4.04 \mathrm{I}(1)=4.78$} \\
\hline $\mathrm{CV} 5 \%$ & \multicolumn{6}{|c|}{ Restricted const. $\mathrm{I}(0)=3.62 \mathrm{I}(1)=4.16 /$ Unrestricted const. $\mathrm{I}(0)=4.94 \mathrm{I}(1)=5.73$} \\
\hline $\mathrm{CV} 1 \%$ & \multicolumn{6}{|c|}{ Restricted const. $\mathrm{I}(0)=4.94 \mathrm{I}(1)=5.58 /$ Unrestricted const. $\mathrm{I}(0)=6.84 \mathrm{I}(1)=7.84$} \\
\hline Coint. Eq. & $\mathrm{UA}=0.96 \mathrm{EU}$ & $\mathrm{UA}=0.95 \mathrm{EU}$ & $\mathrm{UA}=1.08 \mathrm{EU}$ & $\mathrm{UA}=0.90 \mathrm{EU}$ & $\mathrm{UA}=0.33 \mathrm{EU}$ & $\mathrm{UA}=1.07 \mathrm{EU}$ \\
\hline Lag & \multicolumn{6}{|c|}{ Breusch-Godfrey serial correlation LM test (F stat) } \\
\hline 4 & \multicolumn{6}{|c|}{1.712} \\
\hline 8 & \multicolumn{6}{|c|}{1.392} \\
\hline Variable & \multicolumn{6}{|c|}{ ADF test statistics } \\
\hline UA & -1.528 & $-2.735^{*}$ & -1.675 & $-3.348 * *$ & $-4.538 * * *$ & -2.079 \\
\hline d_UA & $-6.719 * * *$ & $-5.239 * * *$ & $-4.546^{* * *}$ & $-3.947 * * *$ & $-9.335^{* * *}$ & $-11.638 * * *$ \\
\hline EU & 0.904 & -2.110 & -1.952 & -1.962 & -2.465 & -2.341 \\
\hline d_EU & $-12.228 * * *$ & $-13.383 * * *$ & $-3.555^{* * *}$ & $-10.273 * * *$ & $-13.401 * * *$ & $-7.496^{* * *}$ \\
\hline Independent var. & \multicolumn{6}{|c|}{ Toda-Yamamoto causality test statistics } \\
\hline UE & $6.652 * * *$ & $3.213 * * *$ & $7.138 * * *$ & $4.505 * * *$ & 0.115 & $16.330 * * *$ \\
\hline UA & $3.078^{* *}$ & 1.762 & $3.061 * * *$ & 0.550 & $5.143 * * *$ & 1.390 \\
\hline
\end{tabular}

Source: the authors' study

Table 6: ARDL-ECM(6,3) model with 5 breaks (HAC estimation).
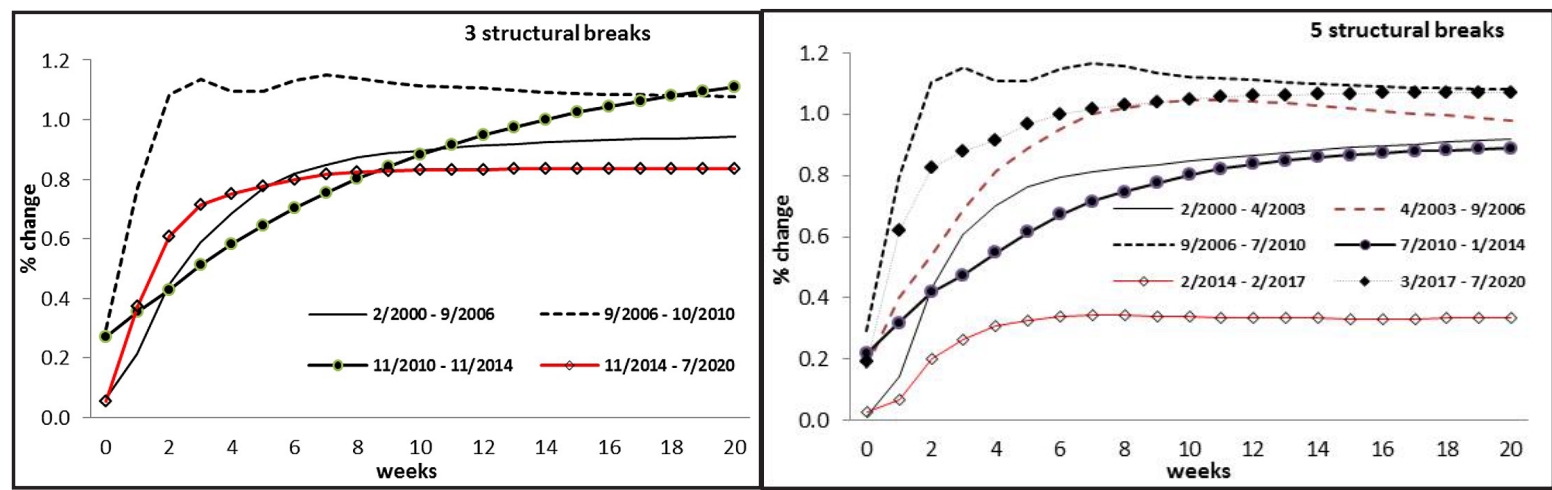

Source: the authors' study

Figure 2: Cumulated impulse response functions for the ARDL(6,3) models with 3 and 5 structural breaks (\%).

to February 2017 (see the model with 5 structural breaks). Firstly, the pressure on the use of biofuels of the first generation in the EU decreased significantly after reaching the minimum levels of biocomponents in liquid fuels. Environmental policy and the reorientation from the production of 1 st generation biofuels towards $2^{\text {nd }}$ and $3^{\text {rd }}$ generation biofuels are of key importance here 
(USDA-FAS 2020). As shown by the data (OECD/FAO 2020), biodiesel production from vegetable oil in 2000 accounted for $99 \%$ of biofuel production in the EU, in 2011 it reached $95 \%$, while in 2019 it was only $78 \%$.

Secondly, it coincided with a significant drop in crude oil prices in the world markets in 2014, which reduced the competitiveness of biofuels in relation to conventional fuels. At that time, there were more and more doubts about the economic efficiency of biofuel production as compared to conventional fuels. The political turmoil in Ukraine (the annexation of Crimea in 2014 and the devaluation of the Ukrainian currency) in Ukraine also contributed to the weakening of the relationship between UA and EU prices. It can be concluded that the increase in commercial risk (the possibility of delivering goods under the conditions of possible port blockades) and the exchange rate risk, or the limitation of production opportunities as a result of the occupation of part of Ukraine by Russia or separatist troops was of significant importance for the weakening of the spatial integration of UA and EU sunflower oil markets. This is also confirmed by the stagnation in the export of sunflower oil from Ukraine to the European Union in 2010-2015 (Comtrade 2020).

Since 2017, there has been a noticeable increase in sunflower price transmission between Ukraine and the European Union. The signing of Deep and Comprehensive Free Trade Area (DCFTA) between the EU and Ukraine in 2014 which led among others to remove customs duties on agricultural commodities was here crucial. The DCFTA has been provisionally applied since 1 January 2016 and the Association Agreement formally entered into force on 1 September 2017 following ratification by all EU Member States. Thanks to it, the average annual value of sunflower oil exports from Ukraine to the EU in 20162019 was almost twice as high as in 2010-2015 (Comtrade 2020). Hence, the increase in price integration of analyzed sunflower oil markets in 2017-2020 is accompanied by an increase in the trade flow between Ukraine and the European Union. The situation on the palm oil market may also have contributed to the increase in the integration of the Ukrainian and EU sunflower oil markets. Although the gradual withdrawals of biofuels in the EU with a high risk of indirect land-use change (ILUC) will be implemented since 2021, the EU imposed anti-subsidy duties on palm oil in 2019. This led to a significant drop in palm oil imports in 2019-2020 (Comtrade 2020), which could undoubtedly benefit Ukraine by increasing its exports. Thus, in this period, as a result of changes in the EU trade policy, both the trade creation and trade diversion effects on the sunflower oil market can be seen.

The possible time-varying price transmission between the world and Ukrainian agricultural commodity markets was indicated by Götz et al. (2016). Those authors especially pointed to the time-varying long-run relationship between grain prices in Ukraine and prices worldwide due to the trade restrictions. Also, Hamulczuk et al. (2019) discovered structural changes in the long-run equilibrium relationship between $\mathrm{EU}$ and $\mathrm{UA}$ rapeseed prices as a result of changes in the VAT reimbursement policy in Ukraine. In our case (sunflower prices), the evolution of price transmission speed (booth long-run relationship and short-run adjustment) and the existence of multiple equilibria are caused by a wide spectrum of factors.

\section{Conclusion}

The goal of the paper was to test and present an evaluation of the time-varying integration of UA and EU sunflower oil markets. Estimated ARDLECM models for the entire sample confirmed the existence of a long-run equilibrium relationship between the UA sunflower oil prices and the EU prices. In the long-run, a $1 \%$ increase in EU sunflower oil prices causes the growth of the UA sunflower oil prices ranging from $0.91 \%$ to $1.00 \%$. This confirms the strong integration of these markets in 2000-2020.

However, the Bai-Perron tests confirmed the presence of multiple structural breaks in the estimated ARDL-ECM models. The number of breaks differs between the type of test used and assumed deterministic components. Although it can be concluded from the entire sample that the EU prices are the Granger cause for the UA prices, but in some sub-periods, a bidirectional casualty or causality from the UA to the EU prices may be observed (in 2014-2017).

The estimated ARDL-ECM models with structural breaks allow us to conclude that the short-run and the long-run price adjustments differ significantly over time. Thus, the obtained results confirmed the time-varying integration of the UA and EU sunflower oil markets. Moments of structural breaks and the speed of price transmission may be attributed to various, more or less evident, factors. Factors influencing 
the price adjustment include trade and biofuel policies, changes in crude oil prices, the appearance of economic crises and the supply-demand situation on the sunflower oil market. Generally, in 2000-2010 the price transmission increased along with the sunflower oil demand pressure (caused by the biofuel policy) and an increase in the world crude oil prices. In 2014-2017, the long-run price linkage has weakened due to the saturation of the biofuel market, the fall in world crude oil prices as well as instable political situation in Ukraine. Along with implementation of the DCFTA an increase in the strength of price transmission and trade flow in sunflower oil between Ukraine and the European Union is noticeable.

In the future further alterations may be expected in the strength of price links, however, it is difficult to clearly assess the direction of these changes. The new legislative proposal for a Renewable Energy Directive (called "RED II") in the EU establishes an upper limit for conventional biofuels, starting from $7 \%$ in 2021 and dropping gradually to $3.8 \%$ in 2030 (Directive EU 2015/1513). This policy reorientation could reduce the demand for Ukrainian sunflower oil. However, the gradual phasing out of the utilization of palm oil as a feedstock for biofuel production in the EU since 2021 should increase the EU demand for sunflower oil. Moreover, in accordance with the DCFTA, Ukraine agreed to a schedule for decreasing its export duty on sunflower seed exports to all the EU Member States to zero by 2027. This situation may negatively influence the domestic processing capacity due to the growth of the sunflower seed export. Among other factors influencing the development of the UA sunflower production and export opportunities we can list the introduction of possibilities for the buying and selling of agricultural land in Ukraine and guidelines for optimum crop rotations with limits for oilseeds share in the total planted area. The ongoing COVID-19 pandemic is another factor that may influence the integration of global, including EU-UA, oilseed markets.

\section{Corresponding authors}

dr hab. Mariusz Hamulczuk

Warsaw University of Life Sciences - SGGW, Nowoursynowska St. 166, 02-787 Warsaw, Poland

Phone: +48 225934113,_E-mail: mariusz_hamulczuk@sggw.edu.pl

\section{References}

[1] Bai, J. and Perron, P. (2003) "Computation and analysis of multiple structural change models", Applied Economics, Vol. 18, No. 1, pp. 1-22. E-ISSN 1099-1255. DOI 10.1002/jae.659.

[2] Bakucs, Z., Benedek, Z. and Fertö, I. (2019) "Spatial price transmission and trade in the European dairy sector", AGRIS on-line Papers in Economics and Informatics, Vol. 11, No. 2, pp. 13-20. ISSN 1804-1930. DOI 10.7160/aol.2019.110202.

[3] Barrett, C. B. and Li, J. R. (2002) "Distinguishing between Equilibrium and Integration in Spatial Price Analysis", American Journal of Agricultural Economics, Vol. 84, No. 2, pp. 292-307. ISSN 1804-1930. DOI 10.1111/1467-8276.00298.

[4] Barsuk, Y. V. (2017) "Сучасний стан розвитку виробництва та експорту соняшникової олії в Україні. [Online]. Available: http://global-national.in.ua/issue-16-2017/24-vipusk-16-kviten2017-r/2877-barsuk-yu-v-suchasnij-stan-rozvitku-virobnitstva-ta-eksportu-sonyashnikovoji-oliji-vukrajini [Accessed: 06 Oct. 2020]. (In Ukrainian).

[5] Bouët, A., Estrades, C. and Laborde, D. (2012) "Differential Export Taxes along the Oilseeds Value Chain: A Partial Equilibrium Analysis", IFPRI Discussion Paper 01236, pp. 32. [Online]. Available: https://www.ifpri.org/publication/differential-export-taxes-along-oilseeds-value-chain-partialequilibrium-analysis [Accessed: 10 Sept. 2020]. DOI 10.2139/ssrn.2197456.

[6] Braha, K., Rajčániová, M., Qineti, A., Pokrivčák, J. and Lazorčáková, E. (2019) "Evidence of Spatial Price Transmission in the Case of Kosovo", AGRIS on-line Papers in Economics and Informatics, Vol. 11, No. 1, pp. 3-15, ISSN 1804-1930. DOI 10.7160/aol.2019.110101.

[7] Brown, R. L., Durbin, J. and Evans, J. M. (1975) "Techniques for Testing the Constancy of Regression Relationships over Time", Journal of the Royal Statistical Society, Series B (Methodological) 37 , No. 2, pp. 149-92. ISSN 0964-1998. DOI 10.1111/j.2517-6161.1975.tb01532.x. 
[8] Comtrade (2020) "UN Comtrade Database". [Online]. Available: https://comtrade.un.org/ [Accessed: 20 Nov. 2020].

[9] Conforti, P. (2004) "Price transmission in selected agricultural markets", FAO commodity and trade policy research working paper No. 7, pp. 92.

[10] NewClimate Policy Database (2015) "Directive (EU) 2015/1513 of the European Parliament and of the Council of 9 September 2015" [Online]. Available: http://eur-lex.europa.eu/legal-content/ EN/TXT/?uri=CELEX\%3A32015L1513 [Accessed: 06 Oct. 2020].

[11] Fackler, P. L. and Goodwin, B. K. (2001) "Spatial price analysis", Handbook of Agricultural Economics, Vol. 1, Part 2, pp. 971-1024. ISSN 1574-0072. DOI 10.1016/S1574-0072(01)10025-3.

[12] Götz, L., Qui, F., Gervais, J.-P. and Glauben, T. (2016) "Export Restrictions and Smooth Transition Cointegration: Export Quotas for Wheat in Ukraine", Journal of Agricultural Economics, Vol. 67, No. 2, pp. 398-419. E-ISSN 1477-9552. DOI 10.1111/1477-9552.12149.

[13] Goychuk, K. and Meyers, W. H. (2014) "Black Sea and World Wheat Market Price Integration Analysis", Canadian Journal of Agricultural Economics, No. 62, pp. 245-261. E-ISSN 1744-7976. DOI 10.1111/cjag.12025.

[14] Hamulczuk, M., Makarchuk, O. and Sica, E. (2019) "Searching for market integration: evidence from Ukrainian and European Union rapeseed markets", Land Use Policy, Vol. 87, pp. 11. ISSN 0264-8377. DOI 10.1016/j.landusepol.2019.104078.

[15] Kretschmer, B., Bowyer, C. and Buckwell, A. (2012) "EU biofuel use and agricultural commodity prices: a review of the evidence base", Report of the Institute for European Environmental Policy (June), pp. 1-66. [Online]. Available: https://ieep.eu/publications/biofuels-and-agriculturalcommodity-prices-a-review-of-the-evidence-base [Accessed: 03 Aug. 2020].

[16] Kuts, T. and Makarchuk, O. (2020) "Ukrainian Sunflower Market on the Background of EU and US Markets", Problems of World Agriculture, Vol. 20, No. 3, pp. 4-15. E-ISSN 2544-0659, ISSN 2081-6960. DOI 10.22630/PRS.2020.20.3.13.

[17] Listorti, G. and Esposti, R. (2012) "Horizontal price transmission in agricultural markets: fundamental concepts and open empirical issues", Bio-based and Applied Economics, Vol. 1, No. 1, pp. 81-96. E-ISSN 2280-6172. DOI 10.13128/BAE-10769.

[18] Marwa, T., Bashir, A., Azwardi, U., Adam, M. and Thamrin, K. M. H. (2017) "Market Integration of Agricultural Products", International Journal of Economics and Business Administration, Vol. 5, No. 2, pp. 69-82. ISSN 2241-4754. DOI 10.35808/ijeba/130.

[19] OECD/FAO (2020) "OECD-FAO Agricultural Outlook 2020-2029", FAO, Rome/OECD Publishing, Paris. DOI 10.1787/1112c23b-en.

[20] Pesaran, M. H., Shin, Y. and Smith, R. J. (2001) "Bounds Testing Approaches to the Analysis of Level Relationships", Journal of Applied Econometrics, Vol. 16, pp. 289-326. E-ISSN 1099-1255. DOI 10.1002/jae.616.

[21] Potori, N. and Józsa, M. (2014) "Do Black Sea maize prices influence maize futures price discovery in Hungary? An analysis of the relationship between Hungarian and Black Sea maize prices", Studies in Agricultural Economics, Vol. 116, pp. 148-152. E-ISSN 2063-0476, ISSN 1418-2106. DOI 10.7896/j.1417.

[22] Rapsomanikis, G., Hallam, D. and Conforti, P. (2006) "Market integration and price transmission in selected food and cash crop markets of developing countries: review and applications", In: "Agricultural Commodity Market and Trade: New Approaches to Analyzing Market Structure and Instability", eds. A. Sarris and D. Hallam, FAO and Edward Elgar, Cheltenham, pp. 187-217. UK. ISBN-13: 978-1845424442.

[23] Shmygol, N., Antoniuc, A. and Anikieieva, D. (2013) "Експортне мито в Україні. Причини використання та наслідки", Держава і регіони, Vol. 4, No. 73, pp. 16-21. E-ISSN 2707-0719, ISSN 1814-1161. (In Ukrainian). 
[24] Shpychak, O., Lupenko, Y. O., Bodnar, O. V., Kuts, T., Parhomenko, L., Didenko, N., Komarnitska, O. and Seperovych, N. (2015) "Аналіз поточної кон'юнктури і прогноз ринків рослинницької продукції в Україні та світі", monograph, "IAE", pp. 337. (In Ukrainian).

[25] Svanidze, M. and Götz, L. (2019) "Spatial market efficiency of grain markets in Russia: Implications of high trade costs for export potential", Global Food Security, Vol. 21, pp. 60-68. ISSN 2211-9124. DOI 10.1016/j.gfs.2019.07.004.

[26] Toda, H. Y. and Yamamoto, T. (1995) "Statistical Inference in Vector Autoregressions with Possibly Integrated Processes", Journal of Econometrics, Vol. 66, pp. 225-250. ISSN 0304-4076. DOI 10.1016/0304-4076(94)01616-8.

[27] Tulush, L. and Hryshchenko, D. (2018) "Fiscal regulation of oilseed market development in Ukraine", Ekonomika APK, No. 5, pp. 63-76. ISSN 2413-2322.

[28] USDA-FAS (2020) "Global Agricultural Information Network Report, 2000-2020". [Online]. Available: https://gain.fas.usda.gov/\#/ [Accessed: 25 Sept. 2020].

[29] Zilberman, D., Hochman, G., Rajagopal, D., Sexton, S. and Timilsina, G. (2013) "The Impact of Biofuels on Commodity Food Prices", American Journal of Agricultural Economics, Vol. 95, No. 2, pp. 275-281. E-ISSN 1467-8276. DOI 10.1093/ajae/aas037. 